Printed in Great Britain

\title{
SOME RECORDS OF SEA TEMPERATURES IN THE ENGLISH CHANNEL IN FEBRUARY 1963
}

\author{
By N. A. Holme \\ The Plymouth Laboratory \\ (Text-figs. I and 2)
}

The long spell of cold weather, with strong easterly winds, which persisted from just before Christmas 1962, until the end of February 1963, resulted in unusually low sea temperatures in northern Europe. During a cruise in the western English Channel in mid-February, when sea temperatures were near their minimum, a continuous record of surface temperatures was obtained by means of a thermistor towed behind the ship. Although near-zero temperatures such as might cause wholesale mortality of fish and invertebrates (cf. Simpson, I953) were not recorded, the prevailing temperatures (mostly in the range $3^{\circ}-6^{\circ} \mathrm{C}$ ) might be expected to have caused mortalities among some of the warm-water species which normally attain their northern limits in the Channel. A previous instance of mortalities caused by low temperatures in the Channel is recorded by Fauvel (I895), and the present paper provides some data against which the biological effects of the $1962-63$ winter may be assessed.

The first part of the cruise was a hydrographic programme in inshore waters between Plymouth and the Lizard (between about $4^{\circ}$ and $5^{\circ} \mathrm{W}$.), samples being taken at the surface, $10 \mathrm{~m}$ depth, and at $5 \mathrm{~m}$ above the bottom. Surface temperatures have contributed to the data used in mapping the isotherms in Fig. 2, but the whole survey will be published, together with others covering the same area, at a later date. During the second part of the cruise a thermistor unit as described by Booker (196I) was towed behind the ship, surface temperatures being recorded continuously on the paper chart of a Sargent Recorder (Model MR). The thermistor was checked (and in fact calibrated) against the mercury thermometer of a Lumby surface sampler. The accuracy of the record appears to have been better than $\pm 0 \cdot \mathrm{I}^{\circ} \mathrm{C}$, and the recorder could be left unattended for several hours, with occasional adjustments for falling voltage on the standard cells.

In interpreting the results, two questions arise: do the records represent minima for the $1962-63$ winter, and to what extent do surface temperatures represent those of the whole water column? For each area, minimum temperatures will have been reached at different times. Minima would have been most rapidly attained (and passed) in shallow water, while the deeper and relatively warm water towards mid-Channel would have continued to cool for 
several weeks. The only regular records available are those from coastal resorts and harbours where temperatures are taken daily from a pier or quay. Such figures tend to fluctuate from day to day according to the state of the tide, the influence of fresh water from rivers and other local factors, but are some guide to the trend of temperatures in shallow water. Data from Plymouth (Millbay Docks) and Torquay (Fish Quay, $50^{\circ} 27 \frac{1}{2}^{\prime}$ N., $3^{\circ} 31^{1^{\prime}}$ W.) are given in Fig. I.
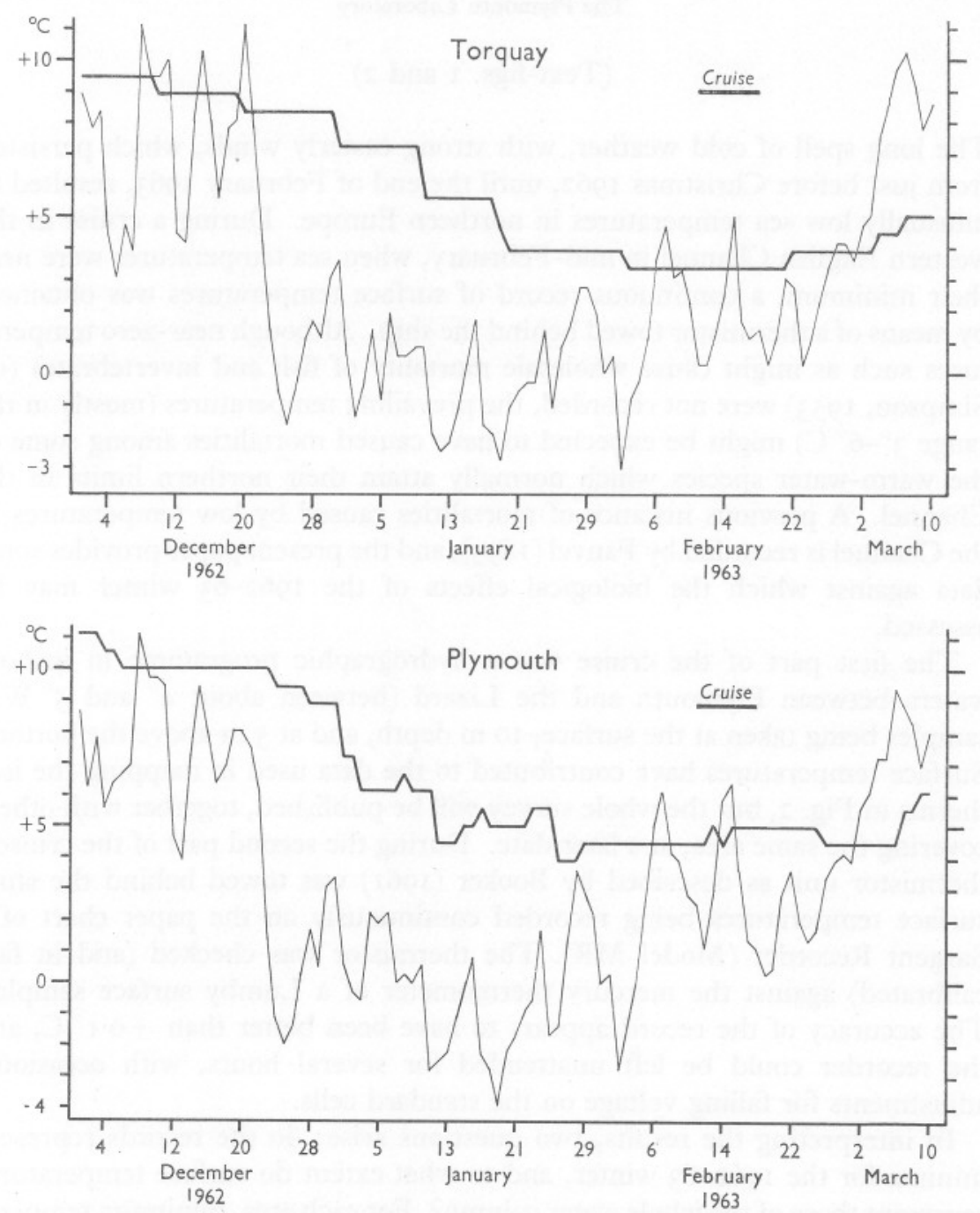

Fig. I. Sea and air temperatures for Torquay and Plymouth. The bold line indicates sea temperatures, measured daily. The air temperatures, indicated by the lighter line, are the mean of shade maximum and minimum temperatures for each day. Temperatures were originally measured in Fahrenheit, to the nearest degree. The duration of the cruise is shown. 
Torquay was chosen as being near the middle of the area investigated and because there is no appreciable freshwater outflow in the neighbourhood. At Plymouth the records are liable to fluctuate more widely due to freshwater influence from the Rivers Tamar and Plym. The February cruise appears to have coincided with minimum sea temperatures at Torquay and was also at a time when mean air temperatures were beginning to approach those of the sea. No doubt lower figures occurred locally in very shallow water in January, and in deep water in mid-Channel minima may not have been reached before the end of February, but it would seem that the cruise gave an opportunity of measuring temperatures little removed from the winter minimum.

In winter there is normally complete vertical mixing in the Channel, so that surface temperatures may be taken to represent those of the whole water column. Locally, however, fresh water at the surface can produce spurious readings. During the cruise some evidence was collected to show that vertical temperature gradients were in fact small:

(I) The hydrographic survey between Plymouth and the Lizard showed a maximum difference between surface and bottom of $0.6^{\circ}$, and out of a total of thirty-three stations the difference was less than $0.2^{\circ}$ at twenty-two stations. Bottom temperatures tended to be slightly higher than those at the surface at all but five stations: in these the trend was reversed.

(2) At certain points during the second part of the cruise the thermistor was lowered to a nominal Io or $17 \mathrm{~m}$ depth. The results (Table I) indicate that the vertical gradient was slight.

(3) There is little evidence of low salinity water at the surface, except at one station (E, Table I), near the mouth of the River Exe. (During this period a slow thaw was in progress, but rivers were described as being at about their normal winter levels.)

The results of the survey are shown in Fig. 2 and in Table I. In interpreting the isotherms it will be remembered that a continuous record of temperature along the ship's course was made, and the isotherms have been drawn in accordance with the accepted pattern of temperature distribution in the Channel (cf. Lumby, 1935). In general, areas inshore and to the east of the last isotherm shown may be expected to be colder, those to the west and offshore should be warmer. The exact position of the isotherms between lines of the ship's track is of course unknown. The region just east of Plymouth was covered three times at intervals of a few days and it has not been possible to indicate the isotherms satisfactorily, as shown by a break in the $5^{\circ}$ line.

The isotherms shown by Lumby (1935) are monthly means for the period I903-27, but unfortunately some of the coastal areas are imperfectly coveredthe isotherms being derived by interpolation or extrapolation. Offshore, temperatures off Plymouth in February 1963 were some $2-3^{\circ}$ below Lumby's figures, $3-4^{\circ}$ lower in Great West Bay, and $4-5^{\circ}$ between Portland and the 
Isle of Wight. In mid-Channel, temperatures were some $2^{\circ}$ below the mean, and about $3^{\circ}$ lower in the Channel Islands. The slow rise in mean sea temperatures during this century suggests that the 1963 values were even further below the average of recent years.

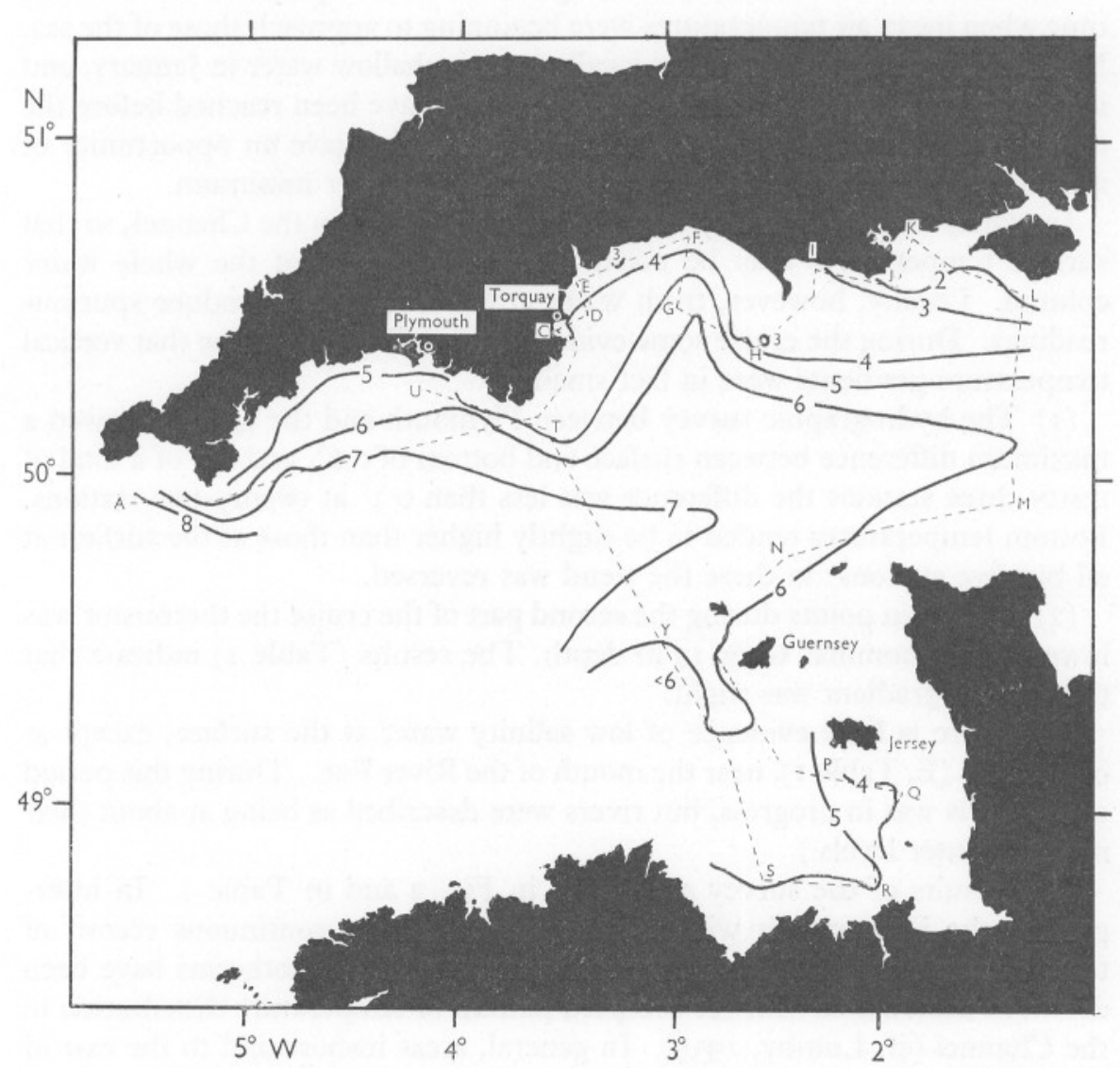

Fig. 2. Sea surface isotherms $\left({ }^{\circ} \mathrm{C}\right)$ for $\mathrm{II}-\mathrm{I} 8$ February $\mathrm{I} 963$. The $5^{\circ}$ isotherm from Plymouth westward is based on the hydrographic programme of II-I2 February. The remaining isotherms are based on towed thermistor readings (broken line), details of which may be abstracted from Table $I$. Towing started at 'A' and ended at ' $U$ ', with breaks in continuity in Torbay on 14 February (delayed $30 \mathrm{~h}$ by gale. Some readings at anchor off Brixham, to the east of 'C'); N.W. of Guernsey (towing restarted on $6^{\circ}$ isotherm as indicated by arrow); and S.W. of Jersey (overnight stop).

A comparison of inshore temperatures at Torquay and Plymouth is given in Table 2, with comparisons with previous monthly means at Plymouth. As with air temperatures, 1963 was most remarkable for the early onset of cold conditions, so that the January figures were well below the average for 
TABLE 1. TEMPERATURES AND SALINITIES AT REPRESENTATIVE POINTS ON TOWED THERMISTOR COURSE (FIG. 2).

(No deductions as to the accuracy of the thermistor should be drawn from these figures, as they were used for drawing the calibration line.)

\begin{tabular}{|c|c|c|c|c|c|c|c|c|}
\hline \multirow[b]{3}{*}{ Station } & \multirow{3}{*}{$\begin{array}{l}\text { Date } \\
\text { (Feb. } \\
\text { I963) }\end{array}$} & \multirow{3}{*}{$\begin{array}{l}\text { Time } \\
\text { G.M.T. }\end{array}$} & \multirow{2}{*}{\multicolumn{2}{|c|}{ Position }} & \multicolumn{2}{|c|}{ Lumby surface sampler } & \multicolumn{2}{|c|}{ Thermistor } \\
\hline & & & & & & Salinity & Depth & ${ }^{\circ} \mathrm{C}$ \\
\hline & & & $\begin{array}{l}\text { N. } \\
49^{\circ} 54 \frac{1}{1}^{\prime}\end{array}$ & $\begin{array}{l}\text { W. } \\
5^{\circ} 33^{\prime}\end{array}$ & $\begin{array}{l}{ }^{\circ} \mathrm{C} \\
8.30\end{array}$ & $\frac{(\%)}{-}$ & $\stackrel{(\mathrm{m})}{-}$ & C \\
\hline A & 13 & I8.13 & $50^{\circ} 03^{\prime}$ & $4.25^{\prime}$ & 6.95 & $35 \cdot 40$ & o & 6.95 \\
\hline - & 13 & 20.22 & $50^{\circ} 06 \frac{1}{2}$ & $3^{\circ} 57^{\prime}$ & 6.63 & 35.40 & o & 6.63 \\
\hline - & 13 & 22.14 & $50^{\circ} 14^{\prime}$ & $3^{\circ} 32^{\prime}$ & $4 \cdot 42$ & $34 \cdot 98$ & $\circ$ & 4.40 \\
\hline - & I4 & 09.12 & $50^{\circ} 25^{\prime}$ & $\begin{array}{l}3^{\circ} 30 \frac{1}{2}^{\prime} \\
\text { or) }\end{array}$ & - & - & 5 & $3 \cdot 70$ \\
\hline - & I4 & 12.00 & ” & & 二 & - & 5 & 3.95 \\
\hline 二 & $\begin{array}{l}\text { I4 } \\
\text { I4 }\end{array}$ & $\begin{array}{l}16.00 \\
18.27\end{array}$ & ", & & 二 & 二 & $\begin{array}{l}5 \\
5\end{array}$ & $\begin{array}{l}4.08 \\
4.10\end{array}$ \\
\hline $\mathrm{C}$ & I5 & 08.48 & $50^{\circ} 26^{\prime}$ & $3^{\circ} 32 \frac{1^{\prime}}{}$ & 3.42 & $34 \cdot 33$ & o & 3.42 \\
\hline $\mathrm{D}$ & I5 & 09.37 & $50^{\circ} 29^{\prime}$ & $3^{\circ} 23^{\prime}$ & $4 \cdot 20$ & $34 \cdot 98$ & $\left\{\begin{array}{r}0 \\
17\end{array}\right.$ & $\begin{array}{l}4 \cdot 20 \\
4 \cdot 25\end{array}$ \\
\hline E & I5 & 10.23 & $50^{\circ} 34^{\frac{1}{2}}$ & $3^{\circ} 26^{\prime}$ & 3.42 & $33 \cdot 96$ & $\left\{\begin{array}{r}0 \\
10 \\
13\end{array}\right.$ & $\begin{array}{l}3.20 \\
3.25 \\
3.35\end{array}$ \\
\hline E-F & 15 & II. $5 \mathrm{I}$ & $50^{\circ} 38 \frac{1^{\prime}}{2^{\prime}}$ & $3^{\circ} 09^{\prime}$ & $3 \cdot 10$ & $35 \cdot \mathrm{II}$ & $\left\{\begin{array}{r}0 \\
17\end{array}\right.$ & $\begin{array}{l}3.10 \\
3.05\end{array}$ \\
\hline $\mathrm{F}$ & I5 & 13.00 & $50^{\circ} 42^{\prime}$ & $2^{\circ} 54^{\prime}$ & 3.05 & $35 \cdot 01$ & $\left\{\begin{array}{r}0 \\
17\end{array}\right.$ & $\begin{array}{l}3.05 \\
3.08\end{array}$ \\
\hline G & 15 & I4.39 & $50^{\circ} 30^{\prime}$ & $2^{\circ} 58^{\prime}$ & 5.92 & $35 \cdot 28$ & $\left\{\begin{array}{r}0 \\
17\end{array}\right.$ & $\begin{array}{l}5.85 \\
5.88\end{array}$ \\
\hline $\mathrm{H}$ & I5 & 17.06 & $50^{\circ} 23^{\prime}$ & $2^{\circ} 35^{\prime}$ & $3 \cdot 62$ & $35 \cdot 13$ & $\left\{\begin{array}{r}0 \\
17\end{array}\right.$ & $\begin{array}{l}3.63 \\
3.40\end{array}$ \\
\hline I & I5 & I9.59 & $50^{\circ} 36^{\prime}$ & $2^{\circ} 18^{\prime}$ & $3 \cdot 20$ & $35 \cdot 07$ & $\left\{\begin{array}{r}0 \\
10\end{array}\right.$ & $\begin{array}{l}3 \cdot 22 \\
3 \cdot 20\end{array}$ \\
\hline $\mathrm{J}$ & I5 & 21.58 & $50^{\circ} 33^{\prime}$ & $\mathrm{I}^{\circ} 55^{\prime}$ & I. $5 \mathrm{I}$ & $34 \cdot 82$ & $\left\{\begin{array}{r}0 \\
17\end{array}\right.$ & $\begin{array}{l}\mathrm{I} \cdot 52 \\
\mathrm{I} \cdot 50\end{array}$ \\
\hline $\mathrm{K}$ & I5 & 22.56 & $50^{\circ} 4 \mathrm{I}^{\frac{1}{2}}{ }^{\prime}$ & $I^{\circ} 49 \frac{1}{2}^{\prime}$ & I.25 & $34 \cdot 3 \mathrm{I}$ & $\left\{\begin{array}{r}0 \\
10\end{array}\right.$ & $\begin{array}{l}1 \cdot 25 \\
1 \cdot 26\end{array}$ \\
\hline $\mathrm{L}$ & I6 & 01.20 & $50^{\circ} 32^{\prime}$ & $I^{\circ} 19^{\prime}$ & $r \cdot 65$ & $34 \cdot 96$ & o & I. 65 \\
\hline M & I6 & $05.5 \mathrm{I}$ & $49^{\circ} 55^{\prime}$ & $I^{\circ} 2 I^{1^{\prime}}$ & 5.57 & $34 \cdot 98$ & o & 5.63 \\
\hline $\mathrm{N}$ & I6 & 10.18 & $49^{\circ} 45^{\prime}$ & $2^{\circ} 26^{\prime}$ & $6 \cdot 30$ & $35 \cdot 26$ & ० & $6 \cdot 28$ \\
\hline$P$ & 17 & 07.53 & $49^{\circ} \circ 7^{\prime}$ & $2^{\circ} 19^{\frac{1}{2}}$ & $4 \cdot 80$ & $35 \cdot 16$ & $\left\{\begin{array}{r}0 \\
17\end{array}\right.$ & $\begin{array}{l}4.83 \\
4.80\end{array}$ \\
\hline Q & I7 & 09.45 & $49^{\circ} \circ 3^{\prime}$ & $\mathrm{I}^{\circ} 54^{\prime}$ & $3 \cdot 8 \mathrm{I}$ & $35 \cdot 10$ & $\left\{\begin{array}{r}0 \\
10\end{array}\right.$ & $\begin{array}{l}3.85 \\
3.73\end{array}$ \\
\hline $\mathrm{R}$ & 17 & II. 54 & $48^{\circ} 45^{\frac{1^{\prime}}{2}}$ & $2^{\circ} \infty 0^{\prime}$ & $5 \cdot 16$ & $35 \cdot 20$ & $\left\{\begin{array}{r}0 \\
17\end{array}\right.$ & $\begin{array}{l}5 \cdot 20 \\
5 \cdot 18\end{array}$ \\
\hline- & 17 & I3.19 & $48^{\circ} 46 \frac{1}{2}^{\prime}$ & $2^{\circ} 15^{\prime}$ & 4.35 & $35 \cdot 16$ & 10 & $4 \cdot 3^{8}$ \\
\hline$s$ & I7 & 14.20 & $48^{\circ} 46_{\frac{1}{2}}^{\prime}$ & $2^{\circ} 32^{\prime}$ & $5 \cdot 30$ & $35 \cdot 22^{\star}$ & $\left\{\begin{array}{r}0 \\
17\end{array}\right.$ & $\begin{array}{l}5 \cdot 30 \\
5.33\end{array}$ \\
\hline $\mathrm{Y}$ & 17 & 20.23 & $49^{\circ} 32^{\prime}$ & $3^{\circ} \circ 4^{\prime}$ & $6 \cdot 08$ & $35 \cdot 35$ & 0 & $6 \cdot 10$ \\
\hline $\mathrm{T}$ & I8 & or. 40 & $50^{\circ} 08^{\prime}$ & $3^{\circ} 34^{\prime}$ & 4.50 & $35 \cdot 16$ & $\circ$ & 4.50 \\
\hline $\mathrm{U}$ & 18 & 04.52 & $50^{\circ} 15^{\frac{1}{2}}$ & $4^{\circ} 09^{\prime}$ & $5 \cdot 75$ & $35 \cdot 32^{\star}$ & $\circ$ & $5 \cdot 78$ \\
\hline
\end{tabular}


previous years. February means were more nearly approached during the cold winter of 1947 , but in that year the January mean was quite high: $8.3^{\circ}$. Even in March 1963, when air temperatures were near average, sea temperatures at Plymouth remained lower than in any previous year since records were started in 1898 .

TABLE 2. MEAN MONTHLY SEA TEMPERATURES $\left({ }^{\circ} \mathrm{C}\right)$ AT TORQUAY AND PLYMOUTH

(Averages for previous years from Cooper (1958).)

\begin{tabular}{|c|c|c|c|c|c|c|}
\hline & \multirow[b]{2}{*}{$\begin{array}{l}\text { Torquay } \\
1962-63\end{array}$} & \multicolumn{5}{|c|}{ Plymouth } \\
\hline & & $1962-63$ & I $946-47$ & $\begin{array}{l}\text { Average } \\
1947-56\end{array}$ & $\begin{array}{l}\text { Average } \\
\text { I898-I952 }\end{array}$ & $\begin{array}{c}\text { Range of } \\
\text { means } \\
1898-1956\end{array}$ \\
\hline $\begin{array}{l}\text { December } \\
\text { January } \\
\text { February } \\
\text { March }\end{array}$ & $\begin{array}{l}8 \cdot 7 \\
5 \cdot 3 \\
3 \cdot 5 \\
-\end{array}$ & $\begin{array}{l}9 \cdot 95 \\
5 \cdot 3 \\
4 \cdot 6 \\
6 \cdot 2\end{array}$ & $\begin{array}{l}9 \cdot 8 \\
8 \cdot 3 \\
5 \cdot 3 \\
6 \cdot 4\end{array}$ & $\begin{array}{r}10.47 \\
8.95 \\
7.86 \\
8.21\end{array}$ & $\begin{array}{l}9 \cdot 94 \\
8 \cdot 83 \\
8 \cdot 06 \\
8.28\end{array}$ & $\begin{array}{r}\text { I2.3-7.2 } \\
\text { I0.6-6.6 } \\
9 \cdot 4-5 \cdot 2 \\
9 \cdot 5-6.3\end{array}$ \\
\hline
\end{tabular}

Many members of the scientific and technical staff of the Plymouth Laboratory have assisted in the development and calibration of the thermistor unit, and I am especially indebted to Mr A. E. Stoate for his skill and patience in constructing the control box. The underwater unit was kindly supplied by the M.A.F.F., Fisheries Laboratory, Lowestoft, and I am grateful to Mr A. J. Lee, Mr D. J. Ellett and Mr G. C. Baxter of that Laboratory for assistance and information. I am indebted to $\mathrm{Mr} \mathrm{E}$. I. Butler for salinity determinations, Mr A. C. G.Best for assistance at sea, and to Captain C. A. Hoodless, R.N.R., and the crew of R.V. 'Sarsia' for working the gear at sea. Temperature data for Torquay and Plymouth are published by kind permission of the Publicity Officer, Torquay, Messrs G. H. Ivory and Partners, Plymouth, and the Medical Officer of Health for Plymouth.

\section{SUMMARY}

In mid-February 1963, a survey of sea temperatures in the western English Channel was made by means of a thermistor towed continuously behind the ship, also by water-bottle samples in a limited area between Plymouth and the Lizard. Evidence is given that surface temperatures, as measured by the thermistor, were representative of the whole water column. Sea temperature records from Torquay indicate that at this time temperatures were near their minimum for this exceptionally cold winter; at Plymouth where sea temperatures are usually more erratic because of estuarine influences the minimum had already been passed. A comparison with data for previous years at Plymouth shows that during January, February and March mean temperatures were lower than in any corresponding month since records were started in 1898 . 


\section{REFERENCES}

Booker, P. G., I96I. New sea temperature measuring devices. f. Cons. int. Explor. Mer, Vol. 26, pp. 133-47.

Cooper, L. H. N., I958. Sea temperatures in Plymouth Sound. 7. mar. biol. Ass. U.K., Vol. 37, pp. I-3.

Fauvel, P., I895. Influence de l'hiver 1894-1895 sur la faune marine. C.R. Acad. Sci., Paris, T. I21, pp. 427-9.

Lumby, J. R., 1935. Salinity and temperature of the English Channel. Atlas of charts. Fish. Invest., Lond., Ser. 2, Vol. 14, No. 3.

Simpson, A. C., I953. Some observations on the mortality of fish and the distribution of plankton in the southern North Sea during the cold winter, 1946-r947. 7. Cons. int. Explor. Mer, Vol. 19, pp. 150-77. 